\title{
Polychlorinated biphenyls in the tributaries of Southern Baikal
}

\section{Gorshkov A.G. ${ }^{1 *}$, Kustova O.V. ${ }^{1}$, Tomberg I.V. ${ }^{1}$, Zhuchenko N.A. ${ }^{1}$, Sakirko M.V. ${ }^{1}$, Khutoryansky V.A. ${ }^{2}$}

${ }^{1}$ Limnological Institute, Siberian Branch of the Russian Academy of Sciences, Ulan-Batorskaya Str., 3, Irkutsk, 664033, Russia

${ }^{2}$ Irkutsk State University, Karl Marx Str., 1, Irkutsk, 664003, Russia

\begin{abstract}
In the aquatic ecosystem of Lake Baikal, global atmospheric transport is regarded as the dominant source of polychlorinated biphenyls (PCBs). Relatively high level of PCB concentration in the southern basin of the lake is associated with PCB influx from local sources. The waters of the tributaries of Southern Baikal, which have watershed basins on the slopes of the Khamar-Daban ridge, possess significant potential as a source of pollutants. The article presents the results of PCBs monitoring in the waters of the rivers Utulik, Solzan, Khara-Murin, Snezhnaya, and Pereemnaya in 2017 and 2019. PCB concentrations in the waters of the tributaries were estimated by the total concentration of seven indicator congeners Nos. $28,52,101,118,138,153$, and $180\left(\Sigma \mathrm{PCB}_{7}\right)$ in water samples taken at the estuaries of the rivers. The $\Sigma \mathrm{PCB}_{7}$ level in the waters - from 0.02 to $1.5 \mathrm{ng} / \mathrm{L}$, can be comparable to or exceed that in the littoral zone of the lake. An assessment of the removal of PCBs to the southern part of Lake Baikal indicates a minimal influx of pollutants of this class with tributary waters. In 2017, the number of PCB indicator congeners that entered Lake Baikal with water runoff was estimated to be between 1.7 and $3.1 \mathrm{~g}$ in May and between 7.7 and $26 \mathrm{~g}$ in September. In extreme conditions, the water runoff of PCBs can reach 40-170 g per month, like in September 2019.
\end{abstract}

Keywords: PCB, waters of tributaries, Lake Baikal

\section{Introduction}

Surface water pollution by persistent organic pollutants (POPs) is one of the most important problems in the world community. The control system of POPs in the water of Lake Baikal, a source of world-class drinking water, pays a special attention to polychlorinated biphenyls (PCBs), because this class of organic pollutants is highly toxic and stable and has the maximum accumulation in biota (Kucklik et al., 1994; Nakata et al., 1995; Samsonov et al., 2017).

Taking into account the widespread use of PCB in electrical equipment of distribution stations, the extent of energy development and the volume of electricity consumption in East Siberia, the influx of PCB to the environment poses the greatest danger to wildlife and human health. The contribution of coplanar (dioxin-like) PCBs to the total toxicity equivalence of dibenzodioxins, dibenzofurans and $\mathrm{PCBs}\left(\mathrm{TEQ}_{1998}\right)$ in commercial fish exceeds 70\% (Mamontov et al., 2000), and in examined people from the Baikal region - 50\% (Shelepchikov et al., 2012).

When PCB was monitored in the Baikal water in 1991-1992 (Iwata et al., 1995; Kucklick et al., 1996), there was a trend toward an increase in the total concentration of congeners $(\Sigma \mathrm{PCB})$ in the upper water layer from the northern to the southern basins of the lake. This trend was associated with the influx of pollutants from local sources to the southern part of Lake Baikal. At the present stage, the assessment of PCB concentration in the Baikal water was carried out by Research and Production Association "Taifun" in 2014 and Limnological Institute SB RAS in 2015 (Gorshkov et al., 2017; Samsonov et al., 2017). Independent studies recorded an increase in $\triangle \mathrm{PCB}$ in the Baikal water: the maximum $\Sigma$ PCB concentration became 3.5 times higher, and the minimum concentration - up to 70 times higher. These studies also revealed maintaining a higher PCB pollution level of the water in the southern basin of the lake (up to two times compared to the northern part of the lake, Gorshkov et al., 2018).

The presence of $\Sigma$ PCB in the atmospheric air of the southern part of Lake Baikal (the 2013-2014 monitoring; weather stations in the Listvyanka, Kultuk and Tankhoy settlements) had a wide range of concentrations, from 7 to $900 \mathrm{pg} / \mathrm{m}^{3}$, and the share of POPs transported in the form of aerosols was $8-12 \%$ of the total amount of substances concentrated from the atmosphere. In particular, at the Tankhoy and Kultuk stations, there were several maximums of $\Sigma \mathrm{PCB}$ concentrations in the 
atmospheric air during the observed season, which were from 3 to 20 times higher than the maximums at the Listvyanka station. The recorded changes in PCB concentrations were explained by the influx of pollutants from local sources to the coast (Samsonov et al., 2017). It should be noted that the PCB content in the soils of Southern Baikal corresponds to the level of soil pollution in the industrially developed areas of northern Europe and is almost five times higher than in areas of Northern Baikal (Mamontov et al., 2018).

The tributaries of Southern Baikal are a highpotential source of pollutants in its ecosystem. These tribitaries have large areas of watershed basins on the slopes of the Khamar-Daban ridge, from 60 to 3000 $\mathrm{km}^{3}$, where a great volume of atmospheric precipitation with high POP concentrations falls due to the transport of the polluted air masses from the industrial zone of the Baikal region and emissions from the sources on the coast (Kokorin and Politov, 1991). Can river runoff be a source of PCBs found in the waters of Lake Baikal, and what is its contribution to lake water pollution? To answer this question, in 2017 and 2019 PCBs were monitored in the waters of the tributaries of Southern Baikal, with water sampling at the estuaries of the rivers, in the littoral and in pelagic zones of the lake along the corresponding sections. PCB concentrations in water samples were estimated by the total concentration of seven indicator congeners, Nos. 28, 52, 101, 118, 138, 153 , and $180\left(\Sigma_{7} \mathrm{PCB}\right)$.

\section{Materials and methods}

Water samples from the tributaries, the littoral zone and pelagic zone of Southern Baikal were taken in May and September of 2017 and 2019 (Fig. 1). Wastewater from the treatment facilities of the town of Severobaikalsk and in the Tyya River was sampled in February 2020. At each station, we took two samples in $1 \mathrm{~L}$ glass bottles, which were covered with a lid having a pad of aluminium foil. Then, $0.5 \mathrm{~cm}^{3}$ of a sodium azide $1 \mathrm{M}$ aqueous solution (High Purity Grade; Merk) was added, and the samples were stored at $+5{ }^{\circ} \mathrm{C}$ in the laboratory until analysis. Indicator PCBs in water samples were determined according to the procedure (FR.1.31.2020.36324). This procedure included the stages of liquid-liquid PCB extraction with $n$-hexane, the concentration of extracts to a volume of $0.1 \mathrm{ml}$ and analysis of concentrates by GC-MS/MS on an Agilent Technologies 7890B GC System 7000C GC/MS Triple Quad gas chromatograph with an HT8 capillary column ( $30 \mathrm{~m} \times 0.25 \mathrm{~mm} \times 0.25 \mu \mathrm{m}$ ). Quantification was carried out according to the method of internal standards using the ${ }^{13} \mathrm{C}_{12}-\mathrm{PCB}$ mixtures (Nos. 28, 52, 101, 118, 138, 153, and 180; Marker-7 PCB Mixture (W/PCB-118)) as surrogate internal standards having a concentration of each congener equal to $0.11 \mathrm{ng} / \mathrm{mL}$ with a relative error $( \pm \delta, \mathrm{P}=0.95)$ of $35 \%$.

The $n$-hexane for chromatography produced by NPK KRIOCHROM LLS (grade 1) which was distilled before analysis, was used for extraction. The purity of the solvents, laboratory ware and chromatographic system was evaluated by conducting blank experiments.

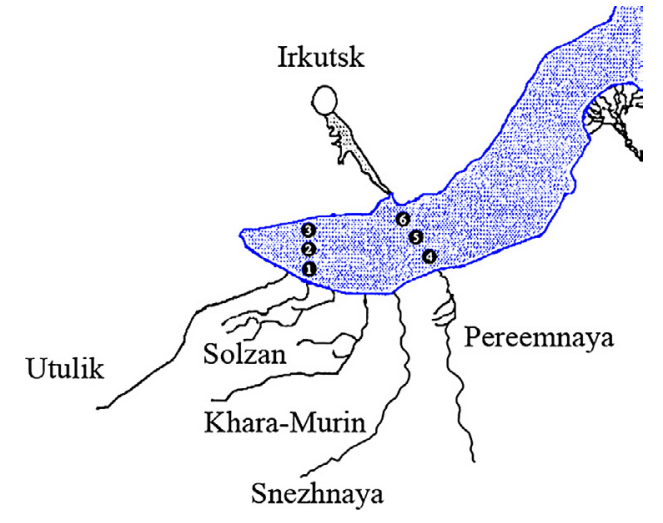

Fig. 1. Scheme of the PCB monitoring site in South Baikal. Sampling at river estuary and in the pelagic zone of a lake, station $\bullet:-1-3 \mathrm{~km}$ from the estuary of the Solzan River; 2 - the Solzan-Marituy section, centre; $3-3 \mathrm{~km}$ from the Marituy settlement; 4 - $3 \mathrm{~km}$ from the Tankhoy settlement; 5 - the Nankhoy-Listvyanka section, centre; 6 - $3 \mathrm{~km}$ from the L.istvyanka settlement.

\section{Results and discussion}

In 2017 and 2019, monitoring PCBs in the rivers Utulik, Solzan, Khara-Murin, Snezhnaya, and Pereemnaya revealed high seasonal and interannual variability of $\Sigma_{7} \mathrm{PCB}$ concentrations (Fig. 2). PCBs were present in the range of $\Sigma_{7} \mathrm{PCB}$ concentrations from 0.02 to $1.5 \mathrm{ng} / \mathrm{L}$ (average value $0.34 \mathrm{ng} / \mathrm{L}$, median 0.20 $\mathrm{ng} / \mathrm{L})$. In the spring of 2017, $\Sigma_{7} \mathrm{PCB}$ concentrations corresponded to the minimum level close to the detection limit of indicator congeners, from 0.02 to 0.09 $\mathrm{ng} / \mathrm{L}$. Repeated monitoring in September indicated that PCB concentration in the waters of tributaries became two-five times higher, and in the Snezhnaya River ten times higher. $\Sigma_{7} \mathrm{PCB}$ concentrations detected in May 2019 were comparable with the results of monitoring conducted in September 2017. However, in the autumn of 2019, we recorded an increase in PCB concentrations. In the rivers Solzan, Khara-Murin and Snezhnaya, $\Sigma_{7}$ PCB concentrations were 3-8 times higher than they were in May 2019, and 10-70 times higher than they were recorded in May 2017.

$\Sigma_{7} \mathrm{PCB}$ concentrations at the estuaries of the rivers could be comparable to or exceed the concentrations in the littoral zone of the lake, for example, in the spring in the Pereemnaya River and along the TankhoyListvyanka section (Fig. 3) as well as in September in the Solzan River and along the Solzan-Marituy section (Fig. 4). Estimation of the influx of PCB to the water of Southern Baikal basin indicates a wide range of masses of this pollutant, which enter the lake with the waters of the tributaries. For instance, in May and September 2017 , the amount of $\Sigma_{7} \mathrm{PCB}$, which entered with water runoff, was minimum, from 1.7 to $3.1 \mathrm{~g}$ and from 7.7 to $26 \mathrm{~g}$, respectively, with the maximum PCB removal with the water from the Snezhnaya River, which has the largest area of watershed basin $\left(3000 \mathrm{~km}^{2}\right)$ (Table).

In the atmosphere and water, PCBs are associated with aerosol particles or suspended matter, which are mainly deposited on the earth's surface near the sources or move to the bottom sediments of 
water bodies. Therefore, PCBs that enter the aquatic ecosystem through the atmospheric channel of from the watershed basin of rivers are identified as fractions of light low-molecular weight PCB congeners having higher volatility and lower hydrophobicity. Owing to these crucial features, mainly tri-, tetra- and pentachlorinated biphenyls represent the composition of PCB in the water.

The number of PCB congeners detected in the Baikal water reaches 34 compounds; their total concentrations range from 1.4 to $7.2 \mathrm{ng} / \mathrm{L}$. Profiles of the homologous groups of PCBs that present in the pelagic zone of the lake are similar and show the dominance of tri-, tetra and penta-chlorinated biphenyls. This homologous ratio indicated the distant atmospheric transport as the main source of PCBs in the aquatic ecosystem. Heavy congeners with a high degree of chlorination detected in the water are due to the influx of PCBs to the water body from local sources (Iwata et al., 1995; Kucklick et al., 1996; Gorshkov et al., 2017; Samsonov et al., 2017).

Indicator congeners (Nos. 28, 52, 101, 118, 138, 153 , and 180) are characterized by a maximum content in the homologous groups of PCBs; their ratio reflects the profile of PCBs present in the studied water object. With a decrease in PCB concentration, the number of congeners available for the quantitation within the standardized control frameworks also decreases. The preservation of a number of controlled congeners requires an increase in the volume of samples, higher sensitivity and reliability of the method at the final stage of determination procedure. Control of PCB in the water object based on the determination of indicator congeners establishes a strict framework for assessing monitoring results, taking into account the constant qualitative composition of the fraction of determined congeners.

In the waters of the Baikal tributaries, we detected seven indicator congeners with the maximum concentrations of tri-, tetra and penta-chlorinated PCBs (Nos. 28, 52, 101, and 118). In samples with minimum PCB concentration in water, at the level of the detection limit of individual congeners equal to $0.01 \mathrm{ng} / \mathrm{L}$, we identified only two-four congeners (monitoring results of May 2017, Fig. 2). At an increase in the PCB content in the water of the tributaries to the level of $\Sigma_{7} \mathrm{PCB}$ equal to 0.02-0.03 ng/L (September 2017, May 2019) there are six compounds in the indicator PCB fraction. Congener No. 180, which contains seven chlorine atoms in the structure, was detected in samples with a relatively high $\Sigma_{7} \mathrm{PCB}$ content, from 0.85 to $1.5 \mathrm{ng} / \mathrm{L}$ (Fig. 2, September 2019). In the indicated season, increased concentrations of $\Sigma_{7} \mathrm{PCB}$ were detected both in the pelagic zone of the lake at the stations Nos 4 and 5 , as well as at the estuary of the Solzan, Khara-Murin and Snezhnaya rivers (Fig. 2, Fig. 3). The analysis of the latter water samples revealed significant scatter in the results of analyte determination: up to seven times. This phenomenon of the composition of the samples might be due to high heterogeneity of the PCB distribution in the river water flow, which occurs when pollutants come from the watershed area.

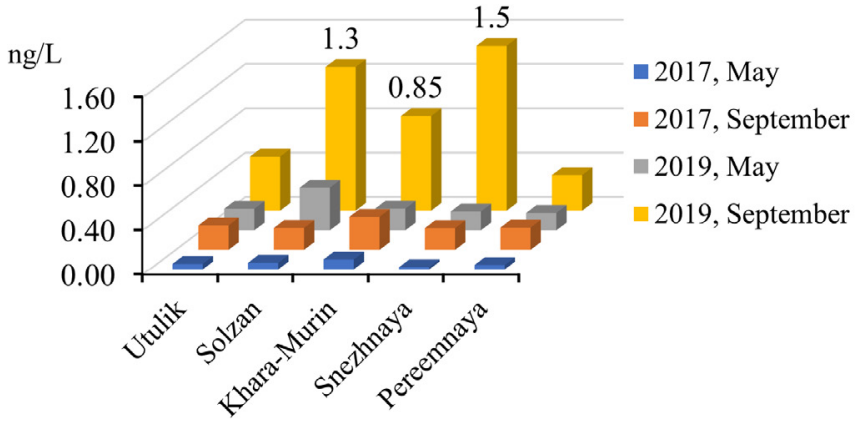

Tributaries

Fig. 2. $\Sigma_{7} \mathrm{PCB}$ concentrations in the tributaries of Southern Baikal.

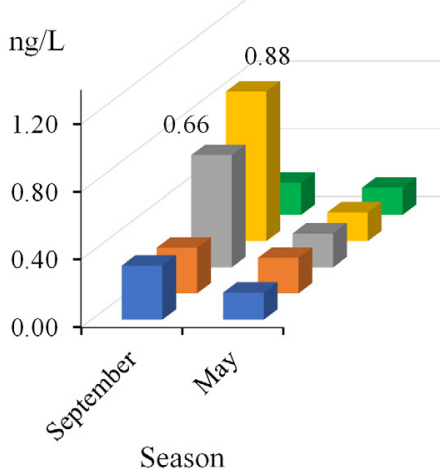

- Pereemnaya River

$100 \mathrm{~m}$ from the estuary of the Pereemnaya River $\because 3 \mathrm{~km}$ from from Tankhoy settlement

The Tankhoy-Listvyanka section, center

घ $3 \mathrm{~km}$ from the Listvyanka settlement

Fig. 3. $\Sigma_{7} \mathrm{PCB}$ concentration at the estuary of the Pereyemnaya River, in the coastal zone and the upper water layer of the Tankhoy-Listvyanka section. Water sampling in May and September 2019.

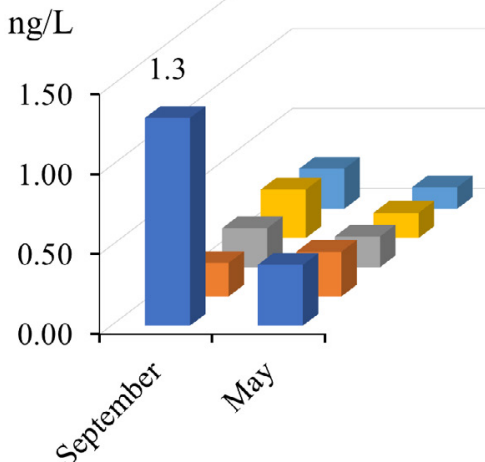

Season
- Solzan River

$100 \mathrm{~m}$ from the estuary of the Solzan River $\because 3 \mathrm{~km}$ from Baikalsk town

The Solzan-Marituy section, center

$\square \mathrm{km}$ from the Marituy settlement
Fig. 4. $\Sigma_{7} \mathrm{PCB}$ concentration at the estuary of the Solzan River, in the coastal zone and the upper water layer of the Solzan-Marituy section. Water sampling in May and September 2019.

When $\Sigma_{7} \mathrm{PCB}$ concentrations and volume of water runoff are at levels of 0.85-1.5 ng/L (Fig. 2) and $0.05-0.13 \mathrm{~km}^{3}$ (Table), respectively, the amount of PCB removal under such conditions can reach 40-190 $g$ per month. PCB influx in such amount is probably associated with the extreme events: global wildfires in East Siberia in 2019 and release of POPs on the slopes of the Khamar-Daban ridge from the atmosphere. The presence of organochlorine pollutants in smokes of wildfires results from their desorption from the vegetation, in which they accumulated during the life cycle when they came from the atmosphere and soil. 
Table. Estimation of the influx of polychlorinated biphenyls ( $\left.\Sigma_{7} \mathrm{PCB}\right)$ in Lake Baikal with the tributaries of Southern Baikal

\begin{tabular}{|c|c|c|c|c|c|c|c|c|}
\hline \multirow[b]{3}{*}{ Tributaries } & \multirow{3}{*}{$\begin{array}{c}\text { Area of } \\
\text { watershed } \\
\text { basin, } \mathrm{km}^{2}\end{array}$} & \multirow{3}{*}{$\begin{array}{l}\text { Average } \\
\text { height } \\
\text { of the } \\
\text { basin, m, } \\
\text { absolute } \\
\text { level }\end{array}$} & \multicolumn{6}{|c|}{ Sampling period } \\
\hline & & & \multicolumn{3}{|c|}{ May, 2017} & \multicolumn{3}{|c|}{ September, 2017} \\
\hline & & & $\begin{array}{c}\sum_{7} \mathrm{PCB}, \\
\mathrm{ng} / \mathrm{L}\end{array}$ & $\begin{array}{c}\text { volume } \\
\text { of water } \\
\text { runoff*, } \\
\mathrm{km}^{3}\end{array}$ & $\begin{array}{c}\sum_{7} \mathrm{PCB} \\
\text { influx, } \mathrm{g}\end{array}$ & $\begin{array}{c}\sum_{7} \Pi \text { ПББ } \\
\text { ng/L }\end{array}$ & $\begin{array}{c}\text { volume } \\
\text { of water } \\
\text { runoff*, } \\
\mathrm{km}^{3}\end{array}$ & $\begin{array}{c}\sum_{7} \mathrm{PCB} \\
\text { influx, g }\end{array}$ \\
\hline the Utulik River & 960 & 1140 & 0.06 & 0.028 & 1.7 & 0.22 & 0.035 & 7.7 \\
\hline the Khara-Murin River & 1130 & 1520 & 0.08 & 0.063 & 5.0 & 0.30 & 0.048 & 14 \\
\hline the Snezhnaya River & 3000 & 1420 & 0.02 & 0.054 & 3.1 & 0.20 & 0.130 & 26 \\
\hline Pelagic zone ${ }^{* *}$ & - & - & 1.1 & - & - & 0.40 & - & - \\
\hline
\end{tabular}

Note: * - Data from the Russian Hydrometeorological Service (Roshydromet); ** - average value for the upper water layer $(5-200 \mathrm{~m})$ in the centre of the Tankhoy-Listvyanka section.

In the context of assessing the influx of PCBs in such amount of interest are the results of determining PCBs in wastewater. PCB content in wastewater discharged into Lake Baikal after passing treatment facilities showed a high content of pollutants of this class. PCB concentration was estimated by the total concentration of the detected congeners equal to 35 $\mathrm{ng} / \mathrm{L}$ (32-24 congeners) as well as $\Sigma_{7} \mathrm{PCB}$ concentration equal to $10 \mathrm{ng} / \mathrm{L}$. At a distance from the sewage discharge collector of up to $2.5 \mathrm{~km}, \Sigma \mathrm{PCB}$ and $\Sigma_{7} \mathrm{PCB}$ concentrations in the Tyya River were 35 times lower, up to a level of 0.95 and $0.31 \mathrm{ng} / \mathrm{L}$, respectively. It should be noted that a decrease in the concentration of PCBs was due to a decrease in the proportion of "light" congeners, and the composition of the PCB fraction corresponded to the PCB content in the tributaries and the upper water layer of the Baikal pelagic zone (Fig 5).

\section{Conclusions}

The waters of the tributaries of Southern Baikal have high seasonal and interannual variability in $\Sigma_{7} \mathrm{PCB}$ concentrations, ranging from 0.02 to $1.5 \mathrm{ng} / \mathrm{L}$, with the dominance of tri-, tetra- and pentachlorinated congeners in the composition. The level of $\Sigma_{7} \mathrm{PCB}$ in the waters of the tributaries can be comparable to or exceed that in the littoral zone of the lake. Assessment of the removal of PCB to the southern part of Lake Baikal with the waters of the tributaries indicates the possible influx of this pollutant to the lake in a wide range of masses, up to two orders of magnitude. According to the monitoring data, masses of PCB indicator congeners that came with water runoff in May and September 2017 correspond to the ranges from 1.7 to $3.1 \mathrm{~g}$ and from 7.7 to $26 \mathrm{~g}$. In extreme conditions, the water runoff of PCBs can reach 40-190 g per month, like in September 2019.

\section{Acknowledgements}

This work was carried out within the framework of the State Task (project No. 0345-2019-0008 (AAAA-A16-116122110065-4) and financial support from the Russian Fund for Basic Research and the Government of the Irkutsk Region (project No. 17-45388077). The chromato-mass-spectrometric analysis

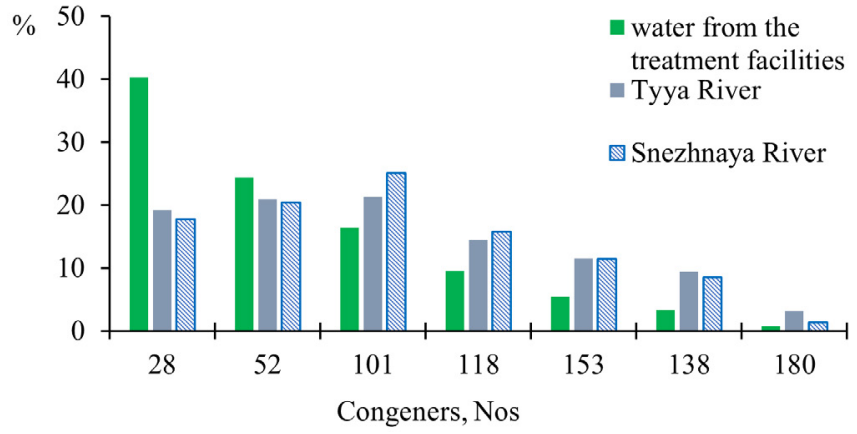

Fig. 5. The proportion of indicator congener PCBs in $\Sigma_{7} \mathrm{PCB}, \%$ :

in wastewater after passing treatment plants in Severobaikalsk, $\Sigma_{7}$ PCB $10 \mathrm{ng} / \mathrm{L}$;

in surface water in the river Tyya, $2.5 \mathrm{~km}$ from the sewage discharge collector, $\Sigma_{7} \mathrm{PCB} 0.31 \mathrm{ng} / \mathrm{L}$;

in water at the estuary of the Snezhnaya River, $\Sigma_{7} \mathrm{PCB}$ $1.5 \mathrm{ng} / \mathrm{L}$.

was conducted at the Collective Instrumental Centre "Ultramicroanalysis" of Limnological Institute SB RAS. The authors thank V.N. Sinyukovich for participating in the discussion of the results.

\section{References}

Gorshkov A.G., Kustova O.V., Dzyuba E.V. et al. 2017. Polychlorinated biphenyls in Lake Baikal ecosystem. Chemistry for Sustainable Development 25: 269-278. DOI: 10.15372/KhUR20170305

Gorshkov A.G., Kustova O.V., Izosimova O.N. et al. 2018. POPs monitoring system in Lake Baikal - impact of time or the first need? Limnolgy and Freshwater Biology 1: 43-48. DOI: 10.31951/2658-3518-2018-A-1-43

Iwata H., Tanabe S., Ueda K. et al. 1995. Persistent organochlorines residues in air, water, sediments, and soils from the Lake Baikal Region, Russia. Environmental Science Technology 29: 792-801. DOI: 10.1021/es00003a03

Kokorin A.O., Politov C.V. 1991. Fallout of pollutants with precipitation in the Southern Area. Meteorologiya i Gidrologia [Meteorology and Hydrology] 1: 48-54. (in Russian)

Kucklik J.R., Bidleman T.F., McConnell L.L. et al. 1994. Organochlorines in the water and biota of Lake Baikal, Siberia. Environmental Science Technology 28: 31-37. DOI: 10.1021/es00050a006 
Kucklick J.R., Harvey H.R., Ostrom P.H. et al. 1996. Organochlorine dynamics in the pelagic food web of Lake Baikal. Environmental Toxicology and Chemistry 15: 13881400. DOI: $10.1002 /$ etc. 5620150819

FR.1.31.2020.36324. Metodika opredeleniya indikatornykh kongenerov polikhlorirovannykh bifenilov $\mathrm{v}$ poverkhnostnykh i glubinnykh vodakh metodom khromatomass-spektrometrii s detektirovaniyem $\mathrm{v}$ rezhime monitoringa zadannykh reaktsiy [Methodology for determination of indicator congeners of polychlorinated biphenyls in surface and deep waters by chromatography-mass spectrometry with detection of predetermined reactions in the monitoring mode]. Irkutsk: Publishing House of the Institute of Geography SB RAS. (in Russian)

Mamontov A.A., Mamontova E.A., Tarasova E.N. et al. 2000. Tracing the sources of PCDD/Fs and PCBs to Lake Baikal. Environmental Science Technology 34: 741-747. DOI: 10.1021/es991047r

Mamontov A.A., Tarasova E.N., Mamontova E.A. 2018. Persistent organic pollutants in soils of Southern Baikal. Russian Journal of General Chemistry 88: 2862-2870. DOI: 10.1134/S1070363218130066

Nakata H., Tanabe S., Tatsukawa R. et al. 1995. Persistent organochlorine residues and their accumulation kinetics in Baikal seal (Phoca sibirica) from Lake Baikal, Russia. Environmental Science Technology 29: 2877-2885. DOI: 10.1021/es00011a026

Samsonov D.P., Kochetkov A.I., Pasynkova E.M. et al. 2017. Levels of persistent organic pollutants in the components of the Lake Baikal unique ecosystem. Russian Meteorology and Hydrology 42: 345-352. DOI: 10.3103/ S1068373917050119

Shelepchikov A.A., Chernyak Yu.I., Brodsky E.S. et al. 2012. Polychlorinated dibenzo-p-dioxins, dibenzofurans and biphenyls in blood serum of firefighters of Irkutsk oblast. Sibirskiy Meditsinskiy Zhurnal (Irkutsk) [Siberian Medical Journal] 3: 53-59. (in Russian) 